\title{
Communication as the Center of Teaching/Learning Process of Foreign Languages (the Case of French Language)
}

\author{
Dr. Leonarda Myslihaka \\ Lecturer of internal University "Aleksander Xhuvani" \\ Humanities faculty, the french branch Elbasan, Albania \\ leomyslihaka@yahoo. it, leomyslihaka@hotmail.com
}

\begin{abstract}
Knowing at least one foreign language has become almost a necessity. However, in learning a foreign language, communication definitely plays a crucial role. Moreover, without communication there is no interaction, language teaching or learning. Communication is considered as very important and more and more is used as a useful tool to organize a pupil - centered lesson. In this article is treated the need to strengthen and highlight the communicative aspects in teaching foreign language, in our case French language, for a better learning of the language. The objective of learning a foreign language is to develop at pupils the communicative competences in this language. More and more we are going towards a method where communication is the one that realizes successfully the process of teaching and learning. The hypothesis that is set in the article is: Is communication the core element in teaching and learning a foreign language? Other research questions and cases that will be treated are: Communication methods of the foreign languages. What communicative skills are required to develop at pupils/students who learn a foreign language and the strategies of their lessons?; Linguistic competences and their communication role; Communication and the importance of interaction; Oral communication in teaching / learning French language, in the French and Italian language department, in "Aleksandër Xhuvani" university, Elbasan.
\end{abstract}

Keywords: communication, foreign language, teaching/learning, teacher/student, strategy, interaction.

\section{Introduction}

Everyone, living in a society, tries to learn how to communicate in a foreign language, using different techniques and methods to achieve this goal. It is difficult to define which the proper method to learn a new language is but we can draw some conclusions on previous experiences. The most used method nowadays is the communicative teaching method, which is considered to be more of an achievement than a real method. As a method it emphasizes the interaction among students and it is called also "communicative achievements in a foreign language". We can classify them in three stages:

Stage 1. Traditional methods (till the 60')

Stage 2. Classical communicative methods (70's - 90's)

Stage 3. Communicative teaching method (90's - nowadays)

We can trace the roots of this method in 1970, in France as a substitute of the previous structuralist method called "Situated language learning". There have been a lot of discussions on the ways we should teach French and how students can use it in their communication and from the observations, we noted that students were capable to articulate sentences correctly during the lesson hours but we had no idea if that happened in real life as well? Some teachers noted that the capability to 
communicate required more than the simple acquaintance with the grammar structures because students are familiar with these rules but not able to communicate according to these rules. So communication required that pupils/students to acquire some lingual functions within a social context. In other words the ability to communicate requires more than a simple lingual competence and it means to know when and how to say something to someone.

\section{Communicative teaching methods in foreign languages}

All communicative teaching methods used today in Albania focus in the communicative acts and the connection with lingual functions. The communicative acts fulfill some functions that represent the aims of the communicator. That said, the learning a language for communicative purposes, aims to apply the theoretical perspective of communicative approach, making the communicative competency the final goal of learning a language. This methods aims as well to go further than simple grammar capacities, in a point where students are able not only to understand a language but to use it in a personal dialogues, so to use the language to achieve a goal. And this is known as a communicative capacity. By encouraging the communicative capacity, the lingual level improves considerably because a language that is used for personal goal is timeresistant in comparison with a language learned by grammar and translation. It emphasizes communication in real life situations and it is quite important in learning a foreign language because it sets a number of important principles to improve students communicative abilities such as:

- Pupils/ students learn the language by communicating it;

-authentic communication and understanding is the final goal of the class;

-Fluency is an important aspect of communication;

-Communication integrates different language abilities;

Another important principle of this method is that the student is in the center of the teaching process and the role of the teacher/ lecturer is quite different than the role in a more traditional class. In traditional classes the teacher/ lecturer has the duty to control while in communicative classes he is more of a facilitator. While in traditional classes is taught more grammar, in communicative classes are created real life situations; grammar is still important but in function of communicating the messages. So as we see, apart the language being studied, the aims remain the same; to develop the communicative competencies. Another aspect is to know the functions in which language is used. Meaning earns the main importance. There are several communicative activities (games, role plays, team work, simulations, solving problems and tasks etc. ) that offer to students a chance to practice their skills in different context and roles, while teachers create the chances for students to use language in a meaningful way. Xhevat Lloshi, in his book "Stilistika dhe Pragmatika e Gjuhës Shqipe (2001:287)": explains that language serves to communicate. Language serves to a number of social functions. When communication happens in social, formal, official or public circumstances, the interaction of lingual factors and social ones brings an organism that is different from discourse. According to him, lingual behavior changes based on social relationships in the moment of conversation, so in the moment that we communicate through speaking or by writing.

Gjovalin Shkurtaj in his book "Etnografia e të Folurit të shqipes (2004:40)" says that the ethnography of speaking follows these questions: Who speaks, with whom, when, for what and what language? Each communicative act, in specific social communities, has had and still has specific norms on which are performed the speech acts". This means that if we do not act as mentioned above, we create a gap between speakers.

\section{What are the required communicative abilities acquired by a student that learns a foreign language and what are the proper strategies to learn them?}

The reason why we learn a foreign language today is mainly concentrated in earning communicative competency, which is developed through teaching and learning of main lingual abilities. "The Common European Framework for lingual references uses the terms: speaking, reading, listening and writing. Each lingual level is described according to the type and level of expressions that students should own in a given level, through communicative and functional examples. To increase these communicative capacities, is important to integrate successfully all these elements with no differences 
among them. Further is stated that in order to accomplish the communicative task, the language users should participate in communicative activities and in this case we can include all lingual competencies. The successful integration and learning depends upon teachers and students, the teaching environment, teaching styles, strategies and the aims of the teacher on how to achieve his objectives. Bardhyl Musai (2003: 22. 30) argues that "the main problem of interactive teaching and learning is that all discursive acts such as listening, speaking, reading and reading should be respected, used and balanced, with the objective that students should participate equally, with all their discursive acts. When students are taught language, they are taught how to listen, read and speak fluently and how to write different texts". That said, the role that these abilities play in the communicative competency is quite important.

We have receiving language abilities ( reading and listening) and giving language abilities ( speaking and writing) and when we study a language, teachers tend to focus only in the language that has to do mainly with grammar, vocabulary, spelling and the development of lingual competencies. The aim of studying a language is to increase the lingual knowledge on receiving and giving lingual abilities.

Meanwhile other studies focused on French curricula as a foreign language, researchers have noted that the lingual competencies are treated separately because they think that it is impossible to treat all these competencies together. This does not help students to improve and use communication outside the class, in real life situations. According to researches, lingual competencies in texts are divided based on learning strategies; reading, listening, speaking and writing. On the other side, grammar is taught inductively and not deductively as in other methods because here the goal is to use grammar to communicate. Same happens with the teaching of vocabulary and pronunciation.

The teaching process and the teacher aims to bring everything into practice, enabling the students to create complete and meaningful sentences and expressions and that is why it is important for them to complete numerous listening and reading task that would help them illustrate the meaning of the vocabulary in a given context. Games, paintings, gestures etc can be used to make the process interesting and fun for the students. "Literary activities are another interesting form for the students to expand their vocabulary and learn syntax" (Trehearne, 2006, p. 31).

We can use different strategies to teach lingual competencies such as self-assessment, questionnaires, analysis, planning and forecasting. Teaching students to improve their learning strategies means to increase their capacities in all lingual competencies and the practical integration of all these competencies through activities and communicative task would improve students' ability to communicate. In a given task could be combined listening, speaking, writing and the use of words and expressions in specific contexts and in this way the students could practice all competencies in simple, practical and communicative way.

\section{Lingual competencies and the role of communication.}

\section{- The importance of reading in communication}

In all French classes reading holds a special place. It is a receiving competency through which students develop their cognitive capacities. In the national language curricula, reading is described as a competency that increase students capacity to communicate and that is why the level of reading in foreign language texts includes the type of expressions that students possess according to their language level. In the same document is stated that students should be exposed with different communicative examples and lingual functions based on their level and this means that reading should not be seen as a simple process but it has to be communicative and to create spaces for students where they can use it.

\section{- The importance of speaking in communication.}

"Speaking is a strong support for reading and writing. It holds a privileged place of personal expression and the first place in the lingual development. The child is developed in the moment when all his lingual capacities to communicate orally are developed too" (Tochon, 1997, p. 11). In CEFR is stated that "the lingual competency to communicate is achieved through the diverse activities that are related with the receiving, production and interaction, completed orally or by text. In the same document is stated the level of speaking that students should possess in each lingual level and in each of these levels the students should be exposed to different communicative examples. In the lower level, students are expected to give short 
answers, to be capable to describe people and places, to use expressions such as permission, requests for help etc while in higher levels students are expected to participate in conversations, to be capable to discuss facts and ideas, to expand their vocabulary and to pronounce words and expressions correctly. Learning French as a second language, requires students to improve their lingual competencies because to speak is one thing, but to communicate is something else and that is why to acquire lingual competencies means to develop receiving and giving capacities.

\section{- The importance of listening in communication}

The majority of people that study French face many difficulties in listening and speaking compared to other competencies. Listening is an important competency in acquiring a new language and it is defined as a key competency for students to be taught effectively. "Students do not listen equally; some stand sit tranquilly, some other move and some other need to see and to listen" (Trehearne, 2006, p. 34). In the national language curricula, listening is given an immense importance. In each language level students have to be exposed to concrete examples and lingual functions. In lower levels students are expected to understand short questions, orders, clear speaking based on non-verbal language as well, while in higher levels students are expected to understand a variety of spoken language from different sources such as: news, journals, documentaries, movies, dramas etc, knowing how to extract conclusions and notice emotional attitudes.

\section{- The importance of writing in communication}

In the national language curricula, writing is again based in the students' level. In each writing level, the students have to be exposed with communicative and functional examples of language. In the lower levels students are expected to reproduce exactly words and sentences, to label objects and to choose words while in the higher level students have to write about real or imaginative topics. They have to be capable to connect sentences, paragraphs and to adapt language. For writing to be functional in communication, the teacher has to use diverse strategies and techniques. To develop creative writing, we need to use all language competencies, critical thinking, and socio-linguistic and cultural competencies. "Actually students acquire $80 \%$ of a competence when they have had the chance to practice it at least 24 times (Anderson, 1995; Newell et Rosenbloom, 1981)". (Hill et Flynn, 2006, p. 10).

\section{Communication and the importance of interaction}

There have been conducted several studies on the role that interaction plays in increasing the communicative competencies in French language. The most important fact is that pupils/ students have to be active in the class and this activism obliges the teacher to speak less and students more. Nowadays, teachers try to direct the teaching process towards students to achieve their objectives and to improve communication among them. Communication teaching oriented methods are based on interaction and one of the main roles of the teacher is to give or create a situation where communication is needed and it is important for students to communicate. They involve themselves actively in communication to create meaning among them even in those situations where they lack complete language competencies. It is the duty of the teacher to incite and motivate them because "Group discussions enhance more the cognitive strategies and in a higher level than individual reasoning practiced during individual learning or competitions"(Giasson, 2003, p. 83).

\section{Types of class interaction}

Interaction is defined as the inclusion of students in the learning process and the cooperation teacher-student and studentstudent.

\section{- Interactive dialogue teacher- students.}

There are two types of interactions: teacher -student and peer-to- peer. The first type of interaction happens between the teacher and many students. The teacher is the one who negotiates with students through explanation, questions, the use of ideas of students etc. This helps students to benefit from the teacher's experience to interact effectively. During this interaction students try to prove their capacities to speak and understand language and how does it help their learning.

- Interactive dialogue student-student / peer-to- peer 
Every teacher should pay the right attention to the relations among students. The communication is achieved through interaction and that is why the activities are chosen wisely to fulfill this objective. Team work and couple work is quite effective and after the teacher defines roles, he/ she monitors them how to complete the task and not to make mistakes. Students are expected to interact with the language system, which is included in the given material. The teacher is responsible to specify the language that students have to use and he/she has to give concrete guidelines because in the contrary the results will not be satisfactory. If this interaction if well-coordinated, it might turn to be a key factor in developing students' cognitive capacities, the development of education, social and cooperation competencies.

\section{- Communicative activities in teaching French as a foreign language.}

Given that speaking is limited within the class, not all students are capable to communicate and not always the tasks are connected with communication, teachers have to find teaching strategies and communicative activities, based on students' age and language level that learn.

\section{Language games, team work and role play}

Games are often used to teach foreign languages because the students' capacity to communicate in this second language. Games require interaction and help to acquire lingual competencies. It is important to stress that in all language level students have to be included in the process of speaking. Pupils/ Students are happy, attracted to these games and if they are built in the right way, they endow students with valuable and practical communicative abilities. Games could be a powerful tool to learn a second language because they encourage, entertain and increase fluency in communication.

- Role play

Role playing is quite important because students are given the chance to practice communication in different social context and social roles. Using this technique, students are involved in an activity where completing the task is much more important than using the right words and when fluency in speaking dominates over accuracy. In order to be successful the teacher should give clear guidelines and each student should know what he/ she has to do, according to the signed role.

\section{- Couple work}

Work in two makes possible the interaction among students in completing the tasks. Based on this technique, students learn from each other, classify and develop new structures and new discursive models.

\section{- Team work}

One of the main teaching principles is to create an active class environment. To secure interaction it is advised to divide the class in small groups that can work harmoniously, expand their learning methods and to create a positive atmosphere where students can exchange information. Same as in role playing team work is quite important and often teachers divide the class in groups to complete specific tasks. The studies have shown that this technique increases efficacy in the teaching process.

\section{Oral communication in French teaching/ learning process, in the department of French and Italian language, in the "Aleksander Xhuvani" University, Elbasan.}

Oral communication plays an essential role in teaching and learning a foreign language. It incites reflection and helps pupils/ students to get included in a constructive dialogue. Oral communication favors phonetic and syntax cognitive development, expands the vocabulary on which students base their understanding, reading, writing and communication in French. That is why those who have good oral skills develop more their competencies in reading and in writing.

"Oral communication is a process of learning and improving that evolves while we experiment techniques and skills that then are put into action, again and again" (Miyata, 2004, p. 113). 
Being conscious about the role and importance that oral communication plays, we conducted some observation hours in the French department, in all bachelor years, in the university "Aleksander Xhuvani" Elbasan. The results of these observations are mentioned below

\section{- First year students' speaking competencies in French language:}

* First year students are capable to participate in short conversations in different situations that are similar with their personal life. They make and understand questions and they can answer with full answers; they communicate by using simple syntax structures.

* In this stage, students continue to develop their auditory and expressing capacities. They understand the message being communicated and try to interact when the other speaker speaks slowly and articulates in a clear way, given time to reflect.

* Students try to explore a variety of topics. They use a simple vocabulary and this helps them to communicate to each other their desires and needs.

* First year students communicate by using the present tense, the past and the future and they try to improve their pronunciation, intonation and rhythm

* They take long pauses with the aim of finding the right words in French and use the proper structures to communicate their message.

\section{- Results of the sophomore students}

* Sophomore students are capable to participate in much more consolidated conversation that are not only related with their personal but also with social life. They understand difficult questions and they try to answer them

* In this stage their capacity to listen and to use oral expressions allows them to participate in different real and interactive situations, communicating easily in French.

* They explore much more complex topics in comparison to first year students and they continue to deepen their vocabulary knowledge and lingual structures. This allows them to express ideas, thoughts and their opinions.

* Sophomore students communicate by using the present, past and future tense more easily than first year students and they try to use other tenses and model verbs to communicate. They have a better pronunciation, rhythm and intonation in French.

* Even though they try to find the right words, they take short pauses and sometimes they correct themselves to speak language more autonomously.

\section{- Last year students:}

* Last year students are capable to participate in more complex and spontaneous conversation connected with personal, social and global aspects of life.

* In this stage, their auditory and oral competency, allows them to communicate among each other in numerous, complex and real situations.

* Students tend to express and justify their opinions and sentiments, giving advices and discussing about different approaches.

* They use tenses and forms based on the context, respecting the pronunciation, rhythm, intonation and syntax structures in French. 
* In this stage they own a rich vocabulary and they try to choose their words attentively. They speak French in a more elaborated language structure and completely autonomous.

\section{Conclusions}

Oral communication is the basis of teaching and learning a foreign language. Only a solid basis of speech enables students to develop better their reading and writing competencies. To learn how to communicate in French the student needs to express his interests and need in original interactive context and firstly he/ she needs to develop the auditory and understanding competencies and to know the purpose of oral communication.

The acquisition of a second language is possible only when the students use language to fulfill any given task with the aim of creating an original communication, having in mind the clarity, fluency and accuracy with which the student expresses his/her ideas.

The student has to use language, structures and vocabulary in different communicative situation, in which social interaction is needed.

Listening is important in this process. "Short, interactive and well- organized activities by the teacher help students to experiment language in a communicative context" (Stewart Cogswell and Kristmanson 2007:24). More, team work creates a spontaneous atmosphere, where the teacher can adapt these activities based on their needs. In this way the student feel much freer and "maximizes his/ her way of using language more independently" (Stewart Cogswell et Kristmanson :24).

Still the teacher/ lecturer remains the principal lingual model that pupils/ students is refereed too, as he/ she is the one who can achieve to create an oral communication by using is personal variations. In the same time, oral presentations such as: (songs, radios, televisions, videos etc) serve as authentic language models.

Last but not least we should emphasize that oral communication is done in two main:

\section{Contextualization (input)}

2. Use (output)

In the first stage pupils/ students learn language unconsciously by listening and understanding real messages that are a bit difficult for them. In this stage the teacher/ lecturer has to be attentive and have in mind their language level in order to progress. Said this, the input should be original and reasonably difficult in order for the student to use language in a proper and meaningful way.

In the second stage, pupils/ students need to be granted the chance to use and re use language in a reasonable level of difficulty and to concentrate on their interests and personal lives. This stage enables pupils/ students to earn oral and linguistic competencies with the objective of communicating their messages independently and effectively.

\section{References}

[1] Giasson, Jocelyne. 2003. La lecture : de la théorie à la pratique, 2e édition. Boucherville, Gaëtan Morin Éditeur Itée.

[2] Hill, Jane D. et Kathleen M. Flynn. 2006. Classroom Instruction that Works with English Language Learners. Virginie (États-Unis), Association for Supervision and Curriculum Development.

[3] Lloshi, Xhevat. Stilistika e gjuhës shqipe dhe pragmatika, botimi dytë. Tiranë, 2001.

[4] Musai, B., Mjeshtëritë themelore të mësimdhënies, Tiranë, 1997 
[5] Miyata, Cathy. 2004. L'art de communiquer oralement. Montréal, Les Éditions de la Chenelière.

[6] Tochon, François Victor. 1997. Organiser des activités de communication orale.

[7] Sherbrooke, Éditions du CRP.

[8] Trehearne, Miriam P. 2006. Littératie en 1re et 2e année - Répertoire de ressources

[9] pédagogiques. Mont-Royal (Québec), Groupe Modulo.

[10] STEWART COGSWELL, Fiona, et Paula Lee, KRISTMANSON (2007). French is a Life Skill, A Summary of Research, Theories and Practices, Toronto, Ontario, Nelson.

[11] Shkurtaj Gj. "Etnografia e të Folurit të shqipes", SHBLU Tirane,, 2004 (277f)

[12] "Kuadri i Përbashkët Evropian i Referencave për Gjuhët" https://www. coe. int//dg4/linguistic/Source/CEFR\%20Albanian. pdf

[13] http://www. botimeshqip. com/liber-mesuesi/190799-kuadri-perbashket-europian-i-referencave-per-gjuhet. html

[14] Kurrikula per Gjuhët e Huaja http://www. arsimi. $\quad$ gov.
al/files/userfiles/kurrikula/PROGRAMI GJUHE SHQIPE, shkalla 3. pdf 